\title{
VENTILATION OF ENGINE ROOMS IN DIESEL ENGINES SHIPS
}

\author{
VictorMihai \\ University "Dunarea de Jos" of Galati, \\ Faculty of Engineering, Galati, 111 Domneasca \\ Street, 800201, Romania, \\ E-mail:victor.mihai@ugal.ro
}

\author{
Liliana Rusu \\ University "Dunarea de Jos" of Galati, \\ Faculty of Engineering, Galati, 111 Domneasca \\ Street, 800201, Romania, \\ E-mail: Liliana.Rusu@ugal.ro
}

\author{
Adrian Presura \\ University "Dunarea de Jos" of Galati, \\ Faculty of Naval Architecture, Galati, 111 Domneasca \\ Street, 800201, Romania, \\ E-mail:adrian.presura@ugal.ro
}

\begin{abstract}
Engine rooms are equipped with a ventilation system which should provide fresh air for combustion and for removing the heat radiated by main engines, auxiliary engines, boilers, generators and other hot equipment installed in compartment. The paper presents the main requirements, recommendations and challenges regarding designing and construction of the ventilation system. The principal design aspects highlighted in this material are related to reducing the pressure drop across the distribution system to reduce the energy used by the fan to blow the air inside the room and to identify the best arrangement of air distribution inlet/outlet in order to get high efficiency of the cooling air.
\end{abstract}

Keywords: engine room ventilation, combustion air, cooling air, pressure drop, air cooling efficiency

\section{INTRODUCTION}

The purpose of this paper is to create an overview about the rules, requirements and recommendations for the design of the engine room ventilation system and to present the main challenges for construction and solutions which should be considered and developed from the first design stage.

It is known that the engine room ventilation system has a great importance for the engine room equipment lifetime but it also has direct implications on the performance of this equipment and for the vessel. The ventilation system has the following purpose:

- providing the air for combustion of the engines and oil-fired boilers,
- cooling of the room by extracting radiated heat,

- $\quad$ to maintain adequate environmental conditions for the crew and equipment

In the last years, the equipment installed in engine rooms have been designed more compact and with increased power, therefore the air flow needed for combustion and cooling have been increased. In the same time, based on new technology for design and construction, the concepts of the vessels were improved for using the spaces more efficient. The vessels become more compact with more spaces reserved for cargo or working areas and less spaces reserved for engine rooms. 
Based on this evolution of ships design, where the engines power and consequently the size of ventilation system have been increased but the space reserved for the engine room have been reduced, the solution for engine room ventilation shall be carefully analyzed starting with the first design stage of the vessel. Then the philosophy of the ventilation system, as well as the location of the main ventilation ducts, supply louvers, fans and the position of air distribution and exhaust must be investigated from the concept design of the vessel to avoid problems later. It should be noted that even if the maker data regarding combustion and heat dissipation is missing in the concept design stage, these data should be estimated according to ISO standards and designer experience.

For main equipment, ISO standard [2] provide enough information to estimate the combustion air and the heat dissipation inside the engine room through the maker data is missing. The air flow needed for engine room ventilation can be calculated using the outside and inside environmental conditions indicated.

In addition, according to IACS M28 (1978) [5], the temperature inside the engine room compartment should be maximum $45^{\circ} \mathrm{C}$ in case the ship is intended for unrestricted service. For vessel not intended for unrestricted navigation, the Classification Society may approve higher temperatures but it cannot be increased over the limitations stated by the engines makers (for example Caterpillar recommend to keep the engine room temperature below $49^{\circ} \mathrm{C}$ otherwise "the cooler air should be ducted directly to the engine air cleaner" [7]).

The lowest temperature for machinery compartments, requested by IACS, is $0^{\circ} \mathrm{C}$ but in general, the temperature inside engines room is kept higher (e.g. above $5^{\circ} \mathrm{C}$ ) by using ventilation fans with variable speed controlled by the temperature inside the room or by installing two or more fans which can be started/stopped when needed.
After the air flow has been calculated the next step is to analyze the equipment arrangement and depending on the main vessel constrain the location of the main supply duct, the position of supply and exhaust louvers and also the position for distribution grilles will be established. For ventilation system arrangement the following should be considered:

- unprotected supply and exhaust louvers to have the openings at $4.5 \mathrm{~m}$ above freeboard deck and $2.3 \mathrm{~m}$ above poop deck (Administration may give some exemptions)

- fresh air inlet should be located far of the heating source and exhaust air outlet

- $\quad$ the fresh air should be discharged in ER as low as possible (close to or below engines floor)

- the exhaust air opening should be located in the highest position of the engine room (in general through the funnel)

- the air distribution inside the engine room should be arranged so that the fresh air to circulate on the floor level, between the engines, from the fresh air inlet to exhaust outlet

- the air distribution ducts should be designed so that the back pressure to be kept as low as possible

- mist eliminator louver should be used for air inlet openings and designed for the velocity of maximum $6 \mathrm{~m} / \mathrm{s}$.

The engine maker has recommendations for the arrangement of ventilation system and indicate the situation where the air flow should be increased up to 2.5 times the air flow calculated according ISO standard.

In order to avoid increasing the air flow up to 2.5 times the air circulation inside compartment should be improved to get a good efficiency of the air cooling.

This goal can be achieved by performing a CFD analysis. 


\section{RULES, STANDARDS AND MAKER REQUIREMENTS}

For the design of engine room ventilation system, IMO and Classification Society rules and recommendation shall be met and also maker requirements and recommendation should be followed.

\subsection{IMO and Classification Society re- quirements}

The IMO rules regarding ventilation system are related to the safety of the vessel and the life (referring Load Line [3], SOLAS [6]) etc.

Therefore, in order to comply with IMO rules, the ventilation ducts for air supply and exhaust should be constructed and located so that the tightness and fire integrity of the watertight and fire divisions are kept according to designed conditions.

For heat balance calculation and other requirements regarding the calculation of the ventilation system, the Classifications Societies are recommending ISO standard 8861 [2].

The main requirements, according to IMO and Classification Society rules, regarding engine room ventilation systems are the followings:

-The engine room ventilation system shall be separated from the ventilation systems serving other spaces.

-The ventilation system shall be designed and built to assure the requested conditions for machinery and boiler operation at the full power, in all weather conditions.

-In general, the ventilation system for engine rooms shall be provided with coaming of $4,5 \mathrm{~m}$ above deck in Position 1 or $2,3 \mathrm{~m}$ above deck in Position 2 without weather tight closing appliances. Nevertheless, the lesser coaming height may be permitted by Administration, if due to the ship size and arrangement the coaming height of $4,5 / 2,3 \mathrm{~m}$ is not practicable. In this case, the ventilation system should be designed "to ensure an uninterrupted, adequate supply of ventila-

(C) Galati University Press, 2020 tion"[1] to the engine room. This can be done by installing weather tight ventilation louvers in the area protected by waves, providing water mist louvers and water traps in ventilation ducts with automatic drainage.

The weathertight closing appliances shall be of steel or equivalent material.

The coaming height of the openings with weathertight covers shall be not less than $900 \mathrm{~mm} / 760 \mathrm{~mm}$ in position $1 /$ position 2 , according to Load Line [3] requirements as indicated in figure 1 and 2.

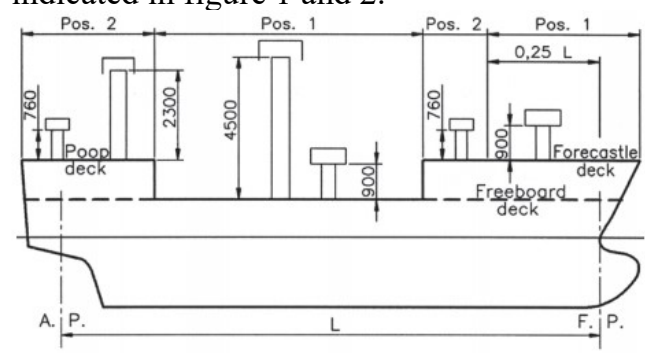

Fig.1 Required ventilation ducts coaming height acc Load Line (Sketch-Wartsilla [9])

\begin{tabular}{|c|c|c|}
\hline Position & I & II \\
\hline $\begin{array}{c}\text { Ventilators } \\
\text { without closures }\end{array}$ & 4500 & 2300 \\
\hline $\begin{array}{c}\text { Ventilators } \\
\text { with closures }\end{array}$ & 900 & 760 \\
\hline
\end{tabular}

Fig.2 Height requirements for ventilation ducts openings on the open deck [3]

In order to avoid short-circuit of air between exhaust and supply air openings the louvers should be installed as far as possible each other's.

-The ventilation system should be designed to be able to remove the smoke in the event of fire. For this purpose, the main ventilation system can use reversible fans.

Where fixed gas fire extinguishing systems based on $\mathrm{CO}_{2}$ are installed, an additional fan with suction below engine room floor is to be provided. It is accepted also that one of the main supply ventilation fans to be reversible. In both cases the fan should be power supplied from emergency source.

-It should be noted that in case of inland vessels with one engine room, which is pro- 
vided with fixed gas fire extinguishing system, the combustion air for main and auxiliary engines shall be taken directly from outside not from the compartment where engines are installed, according to ES-TRIN [4]. This requirement is not applicable to sea going vessels.

-The arrangement of the ventilation system and air distribution inside the engine room should be done so that the accumulation of oil vapors in normal conditions to be avoided.

-The ventilation ducts should be constructed from steel plate or equivalent material. The ventilation ducts for air distribution inside the engine room can be constructed from thin steel plate.

It can be concluded that IMO and Classification Societies rules provide requirements and recommendations related to the safety (the position of louvers on the open deck, penetration of watertight/fire divisions, materials used, some requirements regarding rooms provided with $\mathrm{CO} 2$ etc.), but there are not rules for system calculation and air distribution arrangement.

\subsection{International standard with design requirements and calculation methods for engine room ventilation}

The standard ISO 8861:1998 [2], indicated by Classification Society as reference, specify the calculation method and design conditions to determine the air flow needed for ventilation of the engine rooms.

According to standard requirements, the total air flow for engine room ventilation shall be at least the sum of combustion air and the air flow needed to remove the heat radiated inside the room. In any case, the air flow shall not be less than $150 \%$ of the total combustion air.

Environmental design condition indicated in ISO standard for the calculation are the followings:

- $\quad$ Outside ambient temperature: $+35^{\circ} \mathrm{C}$

- Maximum difference of temperature between supply and exhaust air: $12.5^{\circ} \mathrm{C}$
- Air density (considered for $+35^{\circ} \mathrm{C}$, $70 \% \mathrm{RH}$ and $101.3 \mathrm{kPa}): 1.13 \mathrm{~kg} / \mathrm{m}^{3}$

- Specific heat capacity of the air: $1.01 \mathrm{~kJ} /$ (kg K)

For air flow calculation, maker data regarding heat radiation and combustion air needed should be used. However, in case maker data is missing the air combustion for different equipment can be calculated/estimated based graphs and general data included in the standard as reference.

Combustion air for diesel engines can be calculated as following [2]:

$$
q_{\mathrm{dp}}=\frac{P_{\mathrm{dp}} \times m_{\mathrm{ad}}}{\rho}
$$

$\mathrm{q}_{\mathrm{dp}}$ - air flow for combustion of diesel engines

$\mathrm{P}_{\mathrm{dp}}-$ maximum continuous power of diesel engine

$\mathrm{m}_{\mathrm{ad}}$ - air requirement for combustion of diesel engine, in kilograms per kilowatt second $\mathrm{m}_{\mathrm{ad}}=$ abt. $0.002 \mathrm{~kg} /(\mathrm{kWs})$

$\rho=1.13 \mathrm{~kg} / \mathrm{m}^{3}$, is air density

In the same way, also the combustion air for boilers can be estimated.

The next step is to calculate the air flow needed for the evacuation of the heat emission [2].

$q_{h}=\frac{\phi_{d p}+\phi_{d g}+\phi_{b}+\phi_{p}+\phi_{g}+\phi_{e l}+\phi_{e p}+\phi_{1}+\phi_{0}}{\rho \times c \times \Delta T}-0,4\left(q_{d p}+q_{d g}\right)-q_{b}$

qh- air flow needed for evacuation of heat emission

$\Phi_{\mathrm{dp}}$ - heat emission from main propulsion

$\Phi_{\mathrm{dg}}$ - heat emission from diesel generators

$\Phi_{\mathrm{dg}}-$ heat emission from boiler

$\Phi_{\mathrm{p}}-$ heat emission from hot pipes

$\Phi_{\mathrm{g}}-$ heat emission from el-generator

$\Phi_{\mathrm{el}}$ - heat emission from el-installation

$\Phi_{\text {ep }}$ - heat emission from exhaust pipes

$\Phi_{\mathrm{t}}$ - heat emission from hot tanks

$\Phi_{0}$ - heat emission from other hot components

$\mathrm{d}_{\mathrm{dp}}$ - air flow for combustion of the main propulsion engines

$\mathrm{d}_{\mathrm{dg}}$ - air flow for combustion of the diesel generator

$\mathrm{db}-$ air flow for boiler combustion 
The factor of 0.4 is used for usual engine room arrangement, considering that a part of combustion air will assure also the cooling of the room.

In case maker information regarding heat radiations of equipment is missing, they can be calculated/estimated according to guidance inside standard (using heat loss in percentage from the diesel engine and boiler power; see fig. 3 and fig.4 below for reference)

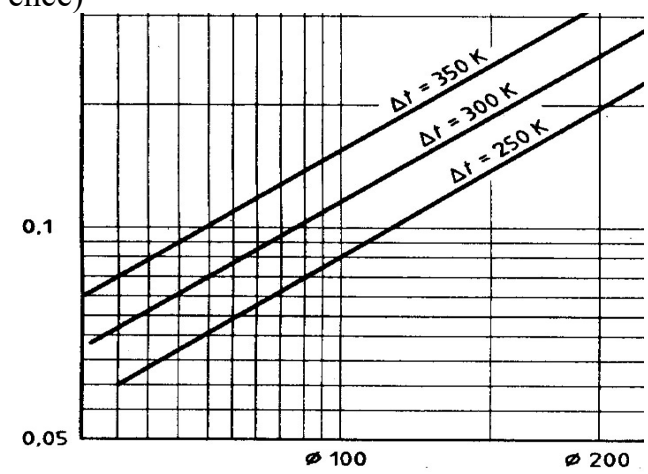

Fig.3 Heat disipation from exhaust pipes in $\mathrm{kW} / \mathrm{m}$ (for $70 \mathrm{~mm}$ heat insulation) [2]

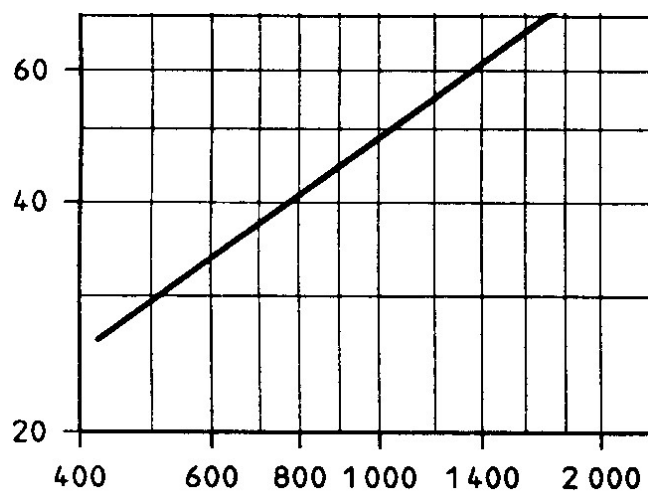

Fig.4 Heat disipation from diesel engines $\mathrm{kW}$ depending on engine power [2]

It should be noted that the calculation of the air flow needed for evacuation of the heat dissipated inside the room is based on the specific heat capacity of the air and heat dissipation, without considering the efficiency of the air distribution.

Given this fact, the main challenge is to find the best solution for air distribution so that the efficiency of the air cooling to be as high as possible and to avoid that a part of air from supply to go outside without cooling the room. It must be said that the ISO standard and IMO or Classification Society rules are not providing information for ventilation system arrangement and distribution in order to obtain a high cooling efficiency.

In these conditions, it can be concluded that the ISO standard provides a calculation method for air flow needed to engine room ventilation but coefficients for air distribution efficiency is not considered.

\subsection{Engine maker requirements and rec- ommendation for engine room ventilation}

In general, reputable manufactures of marine engines provides the guidance for installation of the engines and some requirements and recommendations for engines room ventilation. These requirements should be analyzed together with other rules, vessel constraints and with air flow calculated according to ISO standard.

In many vessels where the ventilation system has been designed according IMO and class rules (including ISO standard) there is enough air for combustion but not enough for removing the heat radiated inside the room and the temperature is increasing in warm weather conditions.

In order to maintain the recommended air temperature inside engine room the arrangement and sizes of distribution ducts should be carefully analyzed.

In line with Caterpillar [7] the following principle should be considered for the design of engine room ventilation system:

- Fresh air inlets should be led as low as possible and as far as possible from the source of heat

- Exhaust to be located as high as possible (preferable above the engine)

- Supply and exhaust grilles to be located as far as possible to avoid recirculation

- The cold combustion air to be led as close as possible to the air filter 
- Avoid mixing cold air with the hottest air (the ventilation system should not blow the air directly to engine components).

Based on different alternatives of ventilation arrangement, Caterpillar [7] provides guidance related routing factors which should be considered:

Type $1-$ is the best ventilation arrangement with the supply ducts routed at the floor level, located between the engines. The exhaust duct is located in the highest point of the engine room (according to figure 5). The routing factor is 1 .

\section{Ventilation Type 1}

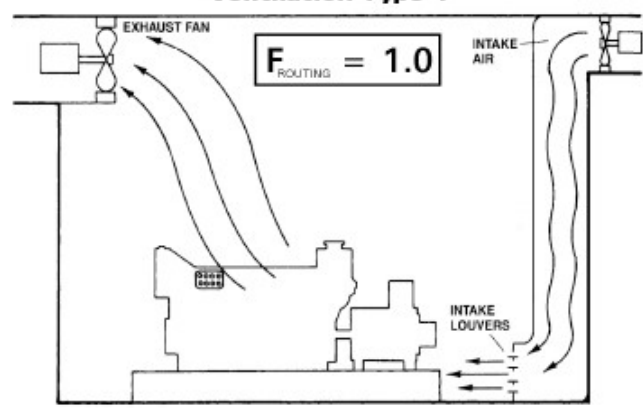

Fig.5 Ventilation arrangement type 1 according to Caterpillar installation guide [7]

Type 2 - is a similar arrangement with type 1 where the air is blowing below the engine room floor, as indicated in figure 6. Although this arrangement has the best efficiency, it is not so practical because under the flor plate, in general, are installed pipes and structural elements which will block the air circulation. Ventilation Type 2

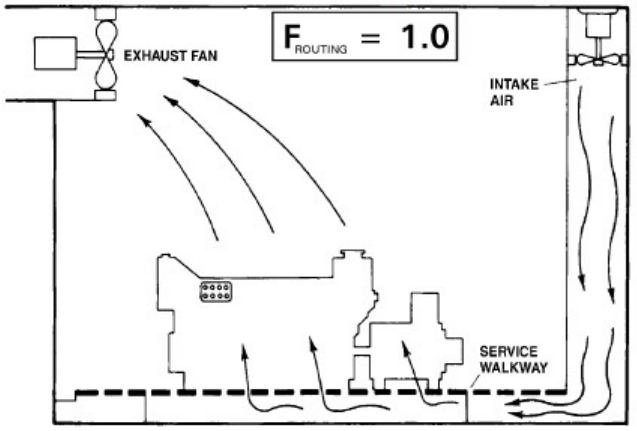

Fig.6 Ventilation arrangement type 2 according Caterpillar installation guide [7]
Type 3 - According to Caterpillar installation guidance, if arrangement type 1 and 2 is not feasible, alternative type 3 can be used but in this case, the maker recommends increasing the air flow with approx. 50\% (figure 3). Routing factor is 1.5 .

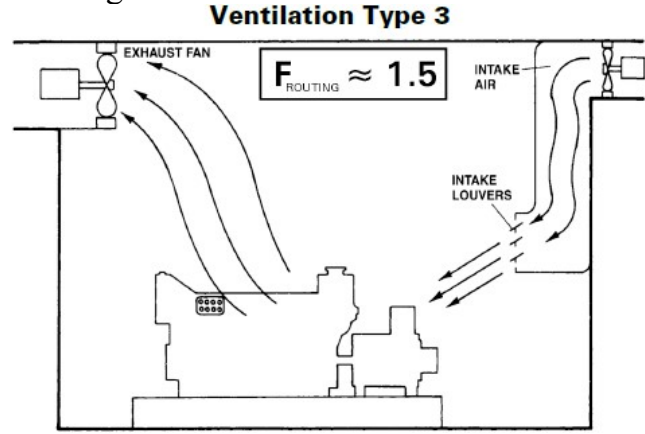

Fig.7 Ventilation arrangement type 3 according Caterpillar installation guide [7]

Type 4- In case of arrangements types 1, 2 or 3 are not feasible the maker accepts the arrangement Type 4 but, in this situation, Caterpiller [7] "requires approximately two and a half times the airflow of Ventilation Type 1. This system mixes the hottest air in the engine room with the incoming cool air, raising the temperature of all air in the engine room. It also interferes with the natural convection flow of hot air rising to exhaust" (fig 8).

The routing factor is 2.5 .

\section{Ventilation Type 4}

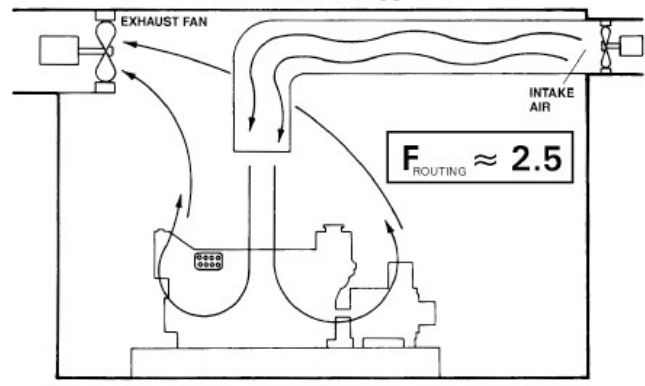

Fig.8 Ventilation arrangement type 4 according to Caterpillar installation guide [7]

For multiple engine installation, the maker recommends that the ventilation air to circulate between the engines, from one side to 
another side of the engine room (figure 9 and 10)

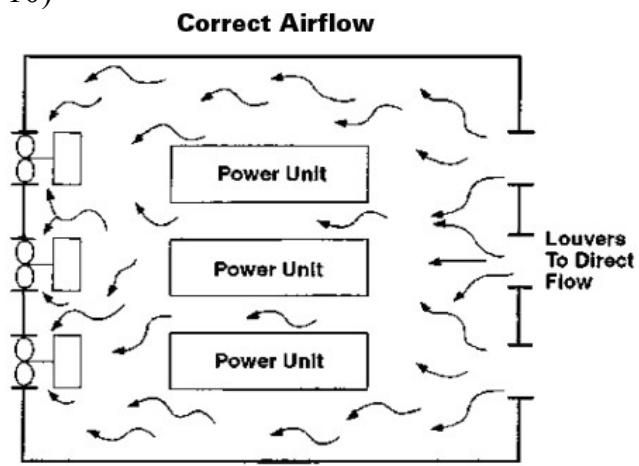

Fig.9 Caterpillar [7] example for correct air flow model in multiple engine installation

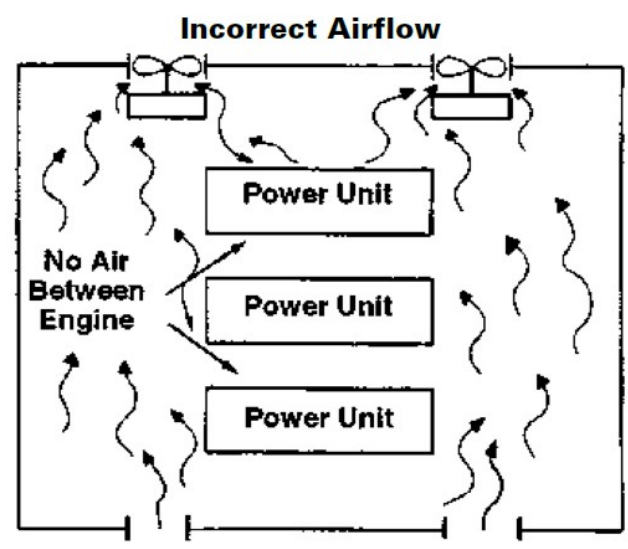

Fig.10 Caterpillar [7] example for incorrect air flow model in multiple engine installation

\subsection{Other design aspects}

In general, the engine room ventilation system, especially for seagoing vessels, is provided with supply louvers with mist eliminator. The mist eliminators louvers are designed to extract the mist and seawater from the air supply. If mist eliminator louvers are not installed, the salt mist will get in the turbocharger where the high temperature will evaporate the water, crystalizing the salt. These minerals deposited into the combustion air system will affect the engine functionality and can also damage the equipment.

(C) Galati University Press, 2020
According to Aeron [8] the mist eliminators have a $100 \%$ efficiency up to air velocity of $4 \mathrm{~m} / \mathrm{s}$ but can be used with good efficiency up to air velocity of $6 \mathrm{~m} / \mathrm{s}$ (figure 11 ).

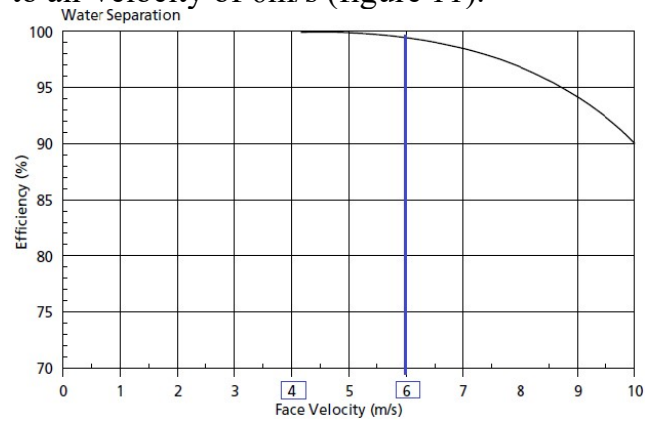

Fig.11 Mist eliminator louver - efficiency of water separation vs air velocity[8]

In addition, the pressure drop across mist eliminator louver must be considered. According to performance data indicated by Aeron the pressure drop will be almost double for increasing of the velocity from $6 \mathrm{~m} / \mathrm{s}$ to $8 \mathrm{~m} / \mathrm{s}$.

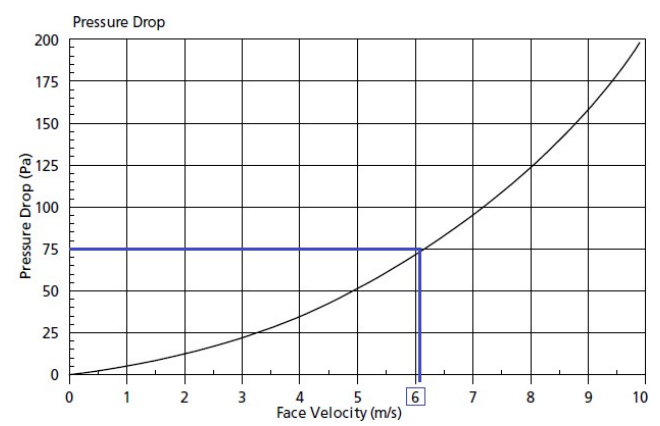

Fig.12 Mist eliminator louver - pressure drop vs air velocity [8]

Considering the analysis above presented, the air supply mist eliminator louver must be installed and the space reserved for installation of such louvers should be big enough in order to keep the velocity across the louver at $\max .6 \mathrm{~m} / \mathrm{s}$.

To provide the adequate quantity of fresh air inside the engine room a powered ventilation system is provided. In general, the fans are designed for air supply but depending on the 
system arrangement, additional exhaust fans can be provided. The system should be designed to maintain a small positive or negative pressure inside the room.

The fan type is determined by the quantity of air flow needed, the pressure drop across the ventilation system and the space limitation. In general, considering the high volume of air needed and low space available the fans used are axial types which are compact and assure a big air flow. (figure 13)

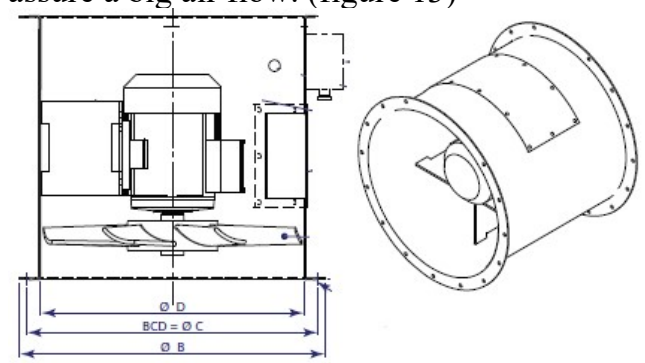

Fig.13 Axial fan example [8]

The down side is that axial fans have low pressure, thus the pressure drop across the ventilation system must be kept as low as possible (figure 14).

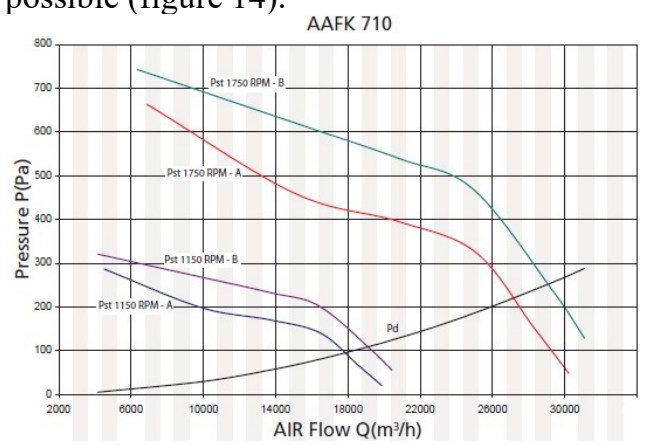

Fig.14 Axial fan characteristic [8]

Taking into consideration the observations made above, in general, axial fans are used for ventilation systems, because they provide high air flow at low power consumption and have a compact design. The main disadvantage is that the air flow can drop drastically if back pressure across the ventilation system increase.

The air distribution inside the engine room, in general, is done using plate steel ducts with thickness of $0.5 \mathrm{~mm}$ to $1.2 \mathrm{~mm}$.
The structural ducts should be used on the deck or bulkhead penetration, only if it is requested. Special attention must be paid to the corners and arrangement of structural elements which can increase significantly the pressure drop across the duct.

\section{DESIGN AND CONSTRUCTION CHALLENGES}

Based on ISO standard the air flow for engine room ventilation is calculated. Considering the vessel arrangement and IMO and class rules the main air supply ducts and the type and number of the fans will be established. An appropriate configuration of the air distribution system can provide a good efficiency of the air cooling.

By reducing the length of the distribution ducts inside the engine room the total pressure drop across the ventilation system will be reduced, therefore the fan operating conditions will be improved.

If the main ventilation ducts cannot be located in a suitable position and additional distribution ducts are necessary, then the sizing and arrangement of the latter ducts should be wisely chosen in order to ensure good operation conditions of the equipment.

The main challenge is to install extensive air ducts inside the engine room, but keeping the access and service spaces for equipment and also the escape routes.

Below are presented some of the compromises that should be done at detail design phase in order to arrange the ventilation ducts inside engine rooms if this aspect was not solved in earlier design stage:

- The ducts are routed underneath hull structural elements but with reduced hight and increased width in order to keep the space for walking., therefore the pressure drop will increase;

- The cross section of the duct is reduced therefore the air velocity and pressure drop will increase;

- The ducts are built structural type keeping the hull structure inside the duct. This solution will increase pressure drop,

(C) Galati University Press, 2020 
because all structural elements will act as multiple diaphragms, as exemplified in figure 13.

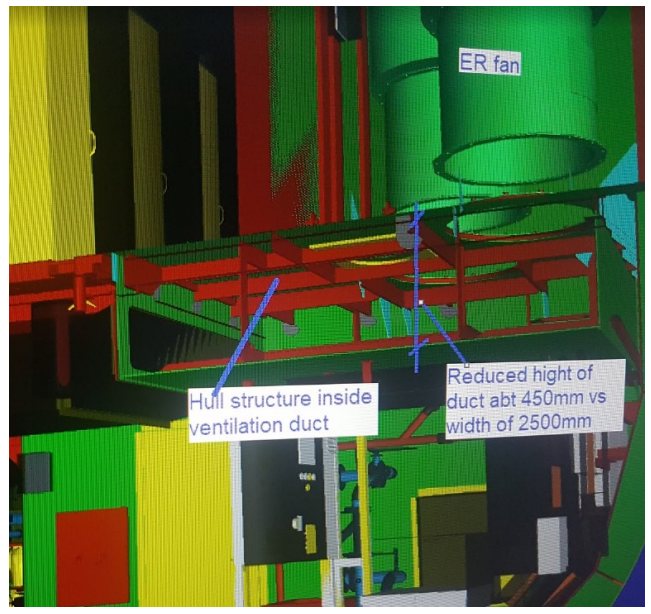

Fig.13 Structural duct example

In these circumstances the pressure drop will increase related to the pressure of the fan and actual air flow inside the engine room will affect the cooling.

In practice are situations when these issues are discovered during the sea trials or in operation when the improvement solutions are limited.

The consequences are the followings:

- The vessel will have limited capabilities in hot environmental conditions

- Increasing the temperature inside the engine room will affect the electrical equipment which can be affected in time

- $\quad$ Engines efficiency can be reduced due to increased air temperature

- High thermal discomfort for the crew involved in engine room activities

\section{CFD ANALYSES}

The main challenge in designing of a proper ventilation system is to assure high efficiency of cooling inside the room and to find the best arrangement for distribution ducts so that the pressure drop to be kept at the minimum possible. In case of maker recommendations can not be followed, due to the con-

(C) Galati University Press, 2020 straints of the vessel arrangement, then increasing the air flow to $150 \% . .250 \%$ is not a desirable solution because of increased ventilation ducts needed and also from economical reason.

In these situations, it is recommended to make an CFD analysis in order to find the best arrangement for air inlet /outlet so that the cooling air to have the best efficiency. In addition, the pressure drop across ventilation ducts will be analyzed in order to find the best arrangement.

Hendri et all [10] by using CFD method have analyzed different ventilation arrangements and finally have reduced the temperature in the engine room of Frigate Class Vessel from $60^{\circ} \mathrm{C}$ to $41^{\circ} \mathrm{C}$ by adding 2 extraction fans and 24outlet ducts.

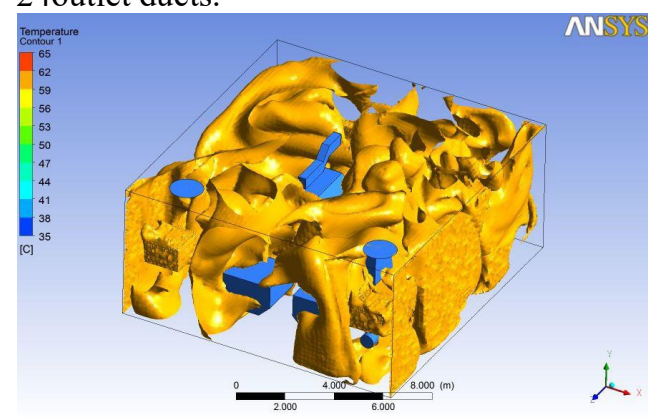

Fig.14 Condition on Iso Surface $60^{\circ} \mathrm{C}$ - before CFD analyses [10]

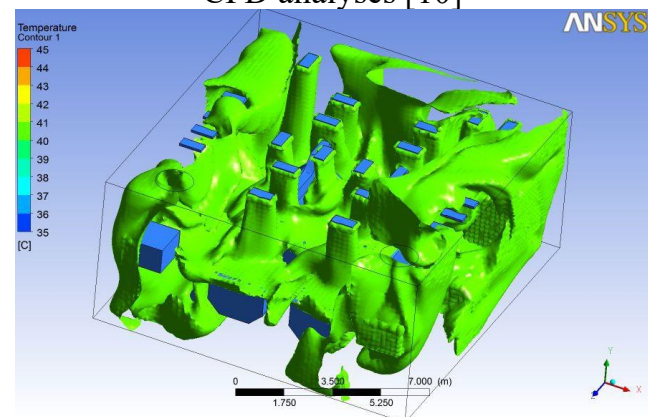

Fig. 15 Condition on Iso Surface $41^{\circ} \mathrm{C}$ - after CFD improvement [10]

\section{CONCLUSIONS}

Engines room ventilation systems should comply with the main requirements and recommendations presented in this article start- 
ing with concept design and followed during detail design. Any compromise regarding air outlets/inlets arrangement and ventilation ducts sizing will affect the cooling capacity of the system.

The followings consequences can appear in case of a poor ventilation system:

- the vessel has limited capabilities in warm environmental conditions

- The efficiency of the engines is reduced during high temperature

- Fuel consumption and air pollution will increase

- Overheating of equipment and damage in time

- Thermal discomfort for the crew members

The main design aspects for ventilation systems are the followings:

- the air flow is calculated according to ISO standard [2],

- the air inlets and outlets are arranged on open deck according to Load Line [3], and to avoid recirculation

- the arrangement of the ventilation system should comply also with maker recommendations.

An important and necessary research goal related to ventilation systems is to develop the direct analysis, with CFD method, of thermal transfer and air flow inside the engine room as an improved method of design.

\section{Acknowledgements}

This paper has been accomplished for the Doctoral School of "Dunărea de Jos" University of Galati, Mechanical engineering, in the frame of Naval Architecture Centre.

\section{REFERENCES}

[1]. DNV-GL I-1-21, "Rules for Classification and Construction, Seagoing Ships, Ventilation"

[2]. ISO-8861: (1998)" Shipbuilding - Engine room ventilation in diesel engine ships - Design requirements and basis of calculation",

[3]. Load Line "International convention of Load line"

[4]. ES-TRIN “European Standard laying down Technical Requirements for Inland Navigation vessels"

[5]. IACS M28 (1978), "Requirements concerning machinery installations - Ambient conditions - Temperatures"

[6]. SOLAS - International Convention for the Safety of Life at Sea

[7]. Caterpillar - LEBW4971-06 Application \& Installation Guide - Engine Room Ventilation

[8]. Aeron - Droplet Separator Louvres \& Filter Coalescor

[9]. Wartsilla - Encyclopedia of ship technology, second edition

[10]. Novi Shobi Hendri, Ahmadi, Okol S Suharyo, Arica Dwi Susanto The Air Flow Analysis in Engine Rooms at Frigate Class Ship with CFD Approach (Computational Fluids Dynamics)

Paper received on October $29^{\text {th }}, 2020$ 